\title{
ANALISIS KELAYAKAN INVESTASI USAHA TERNAK KAMBING PERAH PERANAKAN ETAWAH (Capra aegagrus Hircus) (KASUS DI KELOMPOK TERNAK DELIMA, DESA CIBALUNG KECAMATAN CIJERUK KABUPATEN BOGOR)
}

\author{
SA Rasyid ${ }^{1 \mathrm{a}}$, A Arsyad $^{1}$, A Yusdiarti $^{1}$ \\ ${ }^{1}$ Jurusan Agribisnis, Fakultas Pertanian, Universitas Djuanda Bogor \\ Jalan Tol Ciawi 1, Kotak Pos 35 Bogor 16720 \\ aKorespondensi: Sulaiman Abbas Email : sulaiman.abbas.ras@unida.ac.id
}

\begin{abstract}
ABSTRAK
Penelitian ini bertujuan untuk mengetahui keragaan, kelayakan, dan sensitivitas usaha ternak kambing perah Peranakan Etawah (Capra aegagrus Hircus). Penentuan lokasi dilakukan secara purposive dengan pertimbangan bahwa Desa Cibalung Kecamatan Cijeruk merupakan salah satu daerah yang masih berpotensi untuk peternakan kambing perah. Responden adalah pengurus dan anggota kelompok ternak Delima sejumlah 17 orang. Data dianalisis secara kualitatif dan kuantitatif. Analisis kualitatif digunakan pada kelayakan non-finansial, sedangkan analisis kuantitatif digunakan pada kelayakan investasi secara finansial. Hasil penelitian menunjukkan bahwa keragaan usaha ternak kambing perah Peranakan Etawah di kelompok ternak tersebut adalah : a) sumber modal yang digunakan sebagian besar berasal dari modal sendiri yang dihimpun sebagai modal kelompok; b) sebagian besar anggota tidak berprofesi sebagai peternak melainkan hanya pekerjaan sampingan; dan c) saluran pemasaran yang dilakukan adalah sebagian besar produk susu kambing dijual ke tempat pengolahan. Hasil analisis kelayakan finansial menunjukkan bahwa usaha ini dinyatakan layak dengan hasil kriteria penilaian investasi meliputi NPV sebesar Rp237.425.562, IRR sebesar 27,25 persen, PI sebesar 1,8, serta PP selama 4 tahun 4 bulan. Adapun kelayakan aspek nonfinansial dinyatakan layak dengan persentase evaluasi jawaban 3,4, dan 5 lebih besar dari evaluasi jawaban 1 dan 2, yaitu pada aspek hukum 100 persen dinyatakan cukup layak, aspek pasar 57,6 persen dinyatakan layak, aspek teknis/operasional 79,5 persen dinyatakan layak, aspek manajemen 51,3 persen dinyatakan layak, aspek sosial 44 persen dinyatakan sangat layak, dan aspek dampak lingkungan 92 persen dinyatakan sangat layak. Analisis sensitivitas menunjukkan bahwa maksimum penurunan produksi susu kambing sebesar 93,83 persen, harga jual susu kambing sebesar 93,76 persen, dan harga jual kambing sebesar 80,5 persen.
\end{abstract}

Kata kunci : NPV, IRR, PI, PP, Sensitivitas. 


\section{PENDAHULUAN}

Pada dasarnya peternakan dijalankan untuk memenuhi kebutuhan masyarakat akan pangan hewani. Pangan hewani sebagai produk peternakan yang banyak dihasilkan di Indonesia yakni berupa daging, telur, dan susu. Untuk memenuhi kebutuhan pangan hewani, maka pemerintah bersinergi dengan para peternak mengembangkan dan mewujudkan pendayagunaan sebagian besar komoditas ternak. Salah satu peternakan yang dikembangkan adalah peternakan kambing (Agustina, 2016).

Menurut Badan Pusat Statistik (BPS) tahun 2018, jumlah populasi kambing terutama di Jawa Barat pada tahun 2014 tercatat sebanyak 2.599.380 ekor dan naik sebesar 0,42 persen pada tahun 2015 menjadi sebanyak 2.610.375 ekor. Namun pada tahun 2016 mengalami penurunan yang signifikan sebesar 52,57 persen menjadi 1.237.990 ekor talt kemudian kembali pada trend kenaikan pada tahun 2017 dan 2018 masing-masing sebesar 1,08 persen dan 1,85 persen.

Umumnya, masyarakat Indonesia membudidayakan kambing untuk diperoleh dagingnya. Namun tahun-tahun terakhir ini, kambing mulai dibudidayakan untuk diperoleh susunya, salah satunya melalui jenis kambing Peranakan Etawah (PE). Kambing PE (Capra aegagrus Hircus). dikenal sebagai penghasil susu yang sangat potensial. Hasil penelitian menunjukkan bahwa kambing PE dapat menghasilkan susu sebanyak 0,45 sampai 2,2 liter per hari dengan panjang masa laktasi 92-256 hari. Tingkat produksinya pun masih bisa ditingkatkan dengan manajemen yang baik, seperti pemberian pakan tambahan dan pemilihan bibit yang berkualitas (Sodiq dan Abidin, 2008).

Pemerintah melalui Kementan terus melakukan berbagai upaya dalam peningkatan produksi susu nasional, salah satunya dengan mendorong masyarakat melakukan budidaya ternak kambing perah dari berbagai rumpun jenis kambing termasuk kambing PE. Sebagai penghasil susu, kambing perah memiliki keunggulan kandungan gizi yang lengkap yang dapat meningkatkan kesehatan dan kecerdasan masyarakat. Usaha ternak kambing perah cenderung disukai karena relatif mudah dan cepat menghasilkan. Oleh karena itu dengan pengembangan ternak kambing perah, peningkatan produksi susu nasional dapat ditingkatkan (Salim dan Susanti, 2016).

Sampai saat ini, belum diketahui secara pasti data permintaan susu kambing secara nasional dari BPS maupun lembaga lainnya. Informasi mengenai permintaan susu kambing dapat diketahui dari peternak kambing perah, mendapat permintaan susu kambing sebanyak 15 liter per hari untuk industri pengolahan, namun hanya dapat memenuhi sepertiganya saja.

Penelitian ini dilakukan di Peternakan kambing Desa Cibalung. Peternakan ini didukung dengan keberadaan pertanian yang memasok pakan untuk kambing perah. Kambing merupakan salah satu ruminansia yang mudah dipelihara karena mampu memakan segala jenis rumput bahkan dedaunan. Oleh karena itu, tidak jarang petani atau warga di Desa Cibalung terdorong untuk memeliharanya sehingga terciptalah Kelompok Ternak Delima.

Pihak Kelompok Ternak Delima selama ini belum mampu mengelola produksi susu kambing secara optimal untuk memenuhi kebutuhan pasar per harinya. Beberapa faktor penyebabnya antara lain kurangnya bibit unggul/genetik dan keringnya rerumputan akibat cuaca panas ekstrm yang dialami hampir setiap tahun sehingga produksi susu perah mengalami penurunan.

Oleh karena itu penting dilakukan studi kelayakan usaha ternak kambing PE dengan menganalisis kelayakannya dari aspek finansial (keuangan) dan juga aspek non-finansial sebagai penunjang. Selain itu perubahan-perubahan terhadap volume 
penjualan, harga, dan biaya perlu diperhatikan dan ditinjau agar dapat memenuhi tingkat minimum diterimanya suatu usaha. Berdasarkan uraian tersebut, maka masalah yang dirumuskan dalam penelitian ini adalah 1) Bagaimana keragaan usaha ternak kambing perah Peranakan Etawah di Kelompok Ternak Delima, 2) Bagaimana kelayakan investasi usaha ternak kambing perah Peranakan Etawah di Kelompok Ternak Delima, 3) Berapa besarnya sensitivitas kelayakan usaha ternak kambing perah Peranakan Etawah di Kelompok Ternak Delima?

Tujuan penelitian ini adalah untuk mengetahui keragaan usaha ternak kambing perah Peranakan Etawah, menganalisis tingkat kelayakan investasi usaha ternak kambing perah Peranakan Etawah dan menghitung besarnya sensitivitas kelayakan investasi usaha ternak kambing perah Peranakan Etawah di Kelompok Ternak Delima

\section{BAHAN DAN METODE}

\section{Lokasi dan Waktu Penelitian}

Penelitian ini dilakukan di Kelompok Ternak Delima Desa Cibalung, Kecamatan Cijeruk, Kabupaten Bogor, Provinsi Jawa Barat. Pemilihan lokasi ini ditentukan secara sengaja (purposive) dengan pertimbangan bahwa Desa Cibalung Kecamatan Cijeruk merupakan salah satu daerah yang masih berpotensi untuk peternakan kambing PE. Pengumpulan data di lokasi penelitian dilaksanakan pada bulan September sampai Oktober 2019.

\section{Jenis dan Sumber Data}

Data yang digunakan dalam penelitian ini terdiri atas data primer dan data sekunder. Data primer diperoleh dari hasil pengamatan langsung di lapangan melalui wawancara dengan peternak kambing PE yaitu pihak Kelompok Ternak Delima. Data sekunder akan diperoleh dari berbagai literatur terkait yang bersumber dari BPS, penelitian terdahulu berupa jurnal, buku literatur dan sumber lainnya yang menunjang penelitian.

\section{Metode Penentuan Responden}

Penentuan sampel dalam penelitian ini dilakukan melalui metode nonprobability sampling dengan memilih teknik sampling jenuh (sensus). Responden dalam penelitian ini berjumlah 17 orang berdasarkan data anggota yang terdaftar di Kelompok Ternak Delima di Desa Cibalung Kecamatan Cijeruk Kabupaten Bogor.

\section{Metode Pengolahan dan Analisis Data}

\section{Aspek Non Finansial}

Metode Kualitatif digunakan dalam memperoleh informasi aspek nonfinansial. Pengumpulan data dilakukan dengan observasi, dokumentasi, dan wawancara yang dibantu dengan menggunakan skala Likert. Skala Likert digunakan dengan pemberian angka 5 pada nilai tertinggi dan 1 pada nilai terendah dari jumlah item yang direspon, dimana 5 mewakili "sangat layak", 4 "layak", 3 "cukup layak", 2 "kurang layak", dan 1 "sangat tidak layak".

\section{Penyusutan}

Menghitung penyusutan dapat dilakukan secara komulatif menggunakan persamaan sebagai berikut (Fahmi, 2014) :

1. Untuk menghitung persentase penyusutan dapat dihitung dengan menggunakan persamaan:

$$
\mathrm{Pp}=\frac{\mathrm{Hb}-\mathrm{Hjp}}{\mathrm{Hjp}} \ldots \ldots \ldots \ldots \ldots \ldots \ldots
$$

Keterangan :

$\mathrm{Pp} \quad=$ Persentase penyusutan $(\%)$

$\mathrm{Hb}=$ Harga beli

Hjp = Harga jual yang berlaku di pasar saat ini

2. Untuk mengitung penyusutan per tahunnya dapat menggunakan persamaan yaitu :

$\mathrm{P}=(\mathrm{Hb}-\mathrm{Ns}) \times \mathrm{Pp}_{\mathrm{th}}$ 
Keterangan :

$\begin{array}{ll}\mathrm{P} & =\text { Penyusutan } \\ \mathrm{Hb} & =\text { Harga beli } \\ \mathrm{Ns} & =\text { Nilai sisa } \\ \mathrm{Pp}_{\mathrm{th}} & =\begin{array}{l}\text { Persentase penyusutan per- } \\ \text { tahun }\end{array}\end{array}$

\section{Analisis Kelayakan Finansial}

Kriteria kelayakan finansial yang digunakan dalam penelitian ini diuraikan sebagai berikut (Kasmir dan Jakfar, 2017):

a. Net Present Value

Net Present Value (NPV) merupakan nilai sekarang dari selisih antara manfaat dengan biaya pada tingkat bunga tertentu. Rumusan yang biasa digunakan dalam menghitung NPV sebagai berikut :

$$
\begin{aligned}
\mathrm{NPV}= & \frac{\text { Kas bersih } 1}{(1+\mathrm{r})}+\frac{\text { Kas bersih } 2}{(1+\mathrm{r})^{2}}+\ldots+ \\
& \frac{\text { Kas bersih N }}{(1+\mathrm{r})^{\mathrm{n}}}-\text { Investasi } \quad \ldots . .
\end{aligned}
$$

Kriteria penilaian : Jika

$>$ NPV positif, maka investasi diterima;

$>$ NPV negatif, sebaiknya investasi ditolak

b. Internal Rate of Return Internal Rate of Return (IRR) merupakan alat untuk mengukur tingkat pengembalian hasil intern. Cara untuk mencari IRR adalah dengan menggunakan rumus sebagai berikut :

$$
\mathrm{IRR}=\mathrm{i}_{1}+\frac{\mathrm{NPV}_{1}}{\mathrm{NPV}_{1}-\mathrm{NPV}_{2}} \times\left(\mathrm{i}_{2}-\mathrm{i}_{1}\right)
$$

Keterangan :

NPV1 = Net Present Value 1

NPV2 $=$ Net Present Value 2

$\mathrm{i}_{2}=$ Tingkat bunga 1 (tingkat discount rate yang menghasilkan $\mathrm{NPV}_{1}$ )

$\mathrm{i}_{1}=$ Tingkat bunga 2 (tingkat discount rate yang menghasilkan $\mathrm{NPV}_{2}$ )

Kriteria penilaian : Jika

$>$ IRR $>$ bunga pinjaman, maka diterima

$>$ IRR < dari bunga pinjaman, maka ditolak c. Profitability Index

Profitability index(PI) atau benefit and cost ratio (B/C Ratio) merupakan rasio aktivitas dari jumlah nilai sekarang pengeluaran investasi selama umur investasi. Rumusan yang digunakan untuk mencari PI sebagai berikut :

$\mathrm{PI}=\frac{\sum \mathrm{PV} \text { Kas Bersih }}{\sum \mathrm{PV} \text { Investasi }}$

Kriteria penilaian :

$>$ Jika PI $>1$, maka diterima

$>$ Jika PI $<1$, maka ditolak

d. Payback Period

Menghitung metode payback period (PP) dapat dihitung mrnggunakan rumus :

$\mathrm{PP}=\frac{\text { investasi }}{\text { kas bersih/tahun }} \times 1$ tahun

Untuk melihat apakah usaha layak diterima atau tidak dari segi PP, maka hasil perhitungaan tersebut harus sebagai berikut :

$>$ PP sekarang < dari umur investasi

$>$ Dengan membandingkan rata-rata industri unit usaha sejenis

$>$ Sesuai dengan target perusahaan

\section{Analisis Sensitivitas}

Setelah dilakukan perhitungan menggunakan kriteria kelayakan finansial, analisis sensitivitas perlu dilakukan untuk mengukur perubahan-perubahan yang terjadi. Adapun variabel yang digunakan pada analisis sensitivitas pada penelitian ini yaitu:

1. Penurunan jumlah produksi susu kambing

2. Penurunan harga jual susu kambing

3. Penurunan harga jual kambing

Setelah dilakukan identifikasi terhadap variabel-variabel yang diduga sensitif, maka nilai pengganti (switching value) perlu diketahui. Switching value merupakan perhitungan untuk mengukur perubahan maksimum dari perubahan suatu komponen inflow maupun outflow yang masih dapat ditoleransi. Perhitungan ini mengacu pada seberapa besar 
perhitungan yang terjadi sampai NPV sama dengan nol (Gittinger, 2008).

\section{HASIL DAN PEMBAHASAN}

\section{Karakteristik Anggota Kelompok Ternak Delima}

Dari 17 orang anggota Kelompok Ternak Delima, peternak didominasi oleh laki-laki dengan persentase sebesar $100 \%$. Kegiatan usaha ternak kambing PE merupakan pekerjaan berat berupa memarit rumput kemudian menggotong pakan sehingga dibutuhkan tenaga pria untuk efisiensi usaha.

Kisaran umur terbanyak dari 17 orang anggota tersebut berada pada kisaran usia 40 - 49 tahun dengan persentase sebesar 70,59\%, dan persentase terkecil kisaran umur 30-39 tahun sebesar $11,76 \%$. Sebagian besar peternak hanya menempuh pendidikan SLTP/sederajat yaitu sebesar $64,71 \%$, dan peternak yang mampu menempuh peguruan tinggi hanya sebesar $11,76 \%$.

Pengalaman anggota dalam kegiatan usaha ternak kambing perah $\mathrm{PE}$ sebagian besar sudah menempuh lebih dari 20 tahun dengan persentase $82,35 \%$. Sebagian besar anggota menganggap pekerjaan beternak sebagai pekerjaan sampingan dengan persentase $82,35 \%$. Sebagian besar anggota lebih memilih pekerjaan lain seperti buruh, pegawai swasta, dan wirausahawan.

\section{Sumber Modal}

Sumber modal yang ada di Kelompok Ternak Delima berasal dari modal pinjaman dan modal sendiri. Sebagian besar modal Kelompok Ternak Delima berasal dari modal sendiri berkisar $82,35 \%$ yang dihimpun dalam bentuk modal kelompok. Penyertaan modal yang ada bertujuan untuk mengusahakan pembinaan dan fasilitas yang meliputi budidaya ternak kambing, simpan pinjam, sarana produksi yang dibutuhkan anggota, hingga upaya pengembangan usaha.

\section{Populasi Kambing Anggota Kelompok Ternak Delima}

Jumlah kambing yang dimilki anggota mempengaruhi pendapatan anggota dari usaha ternak yang dijalankan. Semakin banyak kambing yang dimiliki anggota, maka semakin besar pula pendapatannya dari usaha ternak tersebut. Banyaknya jumlah ternak yang dimiliki anggota dapat dilihat pada Tabel 1 .

Tabel 1 Rincian Kepemilikan Kambing PE di Kelompok Ternak Delima, 2019

\begin{tabular}{rrr}
\hline Jumlah & Jumlah & \multicolumn{1}{l}{ Persentase } \\
Kepemilikan & $\begin{array}{l}\text { Anggota } \\
\text { Kambing PE }\end{array}$ & \\
\hline$<5$ ekor & 5 orang & $29,41 \%$ \\
$<10$ ekor & 6 orang & $35,29 \%$ \\
$<20$ ekor & 5 orang & $29,41 \%$ \\
$>20$ ekor & 1 orang & 5,88 \\
\hline Jumlah & 17 orang & $100 \%$ \\
\hline
\end{tabular}

Sumber : Data Primer, 2019

Kepemilikan kambing PE oleh anggota sangat beragam. Besarnya perbedaan jumlah kepemilikan kambing PE oleh anggota, memungkinkan ternak untuk dikoloni satu sama lain. Adapun statistik kepemilikan ternak anggota dapat dilihat pada Tabel 2.

Tabel 2 Statistik Kepemilikan Kambing di Kelompok Ternak Delima, 2019

\begin{tabular}{lc}
\hline Kriteria statistik & Keterangan (ekor) \\
\hline Rata-rata & 9,35 \\
Median & 7,00 \\
Modus & 3,00 \\
Jumlah Terbesar & 46,00 \\
Jumlah Terkecil & 2,00 \\
\hline
\end{tabular}

Sumber : Data Primer, 2019

\section{Saluran Pemasaran dan Kemitraan}

Saluran pemasaran pada Kelompok Ternak Delima terdiri atas 3 pola saluran pemasaran, diantaranya;

Saluran 1 : Kelompok Ternak Delima Tempat Pengolahan

Saluran 2 : Kelompok Ternak Delima pedagang 
Saluran 3 : Kelompok Ternak Delima konsumen akhir

Adapun kemitraan yang dilakukan Kelompok Ternak Delima diantaranya ;

1. Gapoktan Wanti Asih

Tempat barter antara pupuk kandang yang diproduksi oleh pihak Kelompok Ternak Delima dengan limbah sayuran hasil panen petani anggota poktan.

2. Perdana Mandiri Sejahtera

Tempat pengolahan/industri hasil ternak kambing perah dimana Kelompok Ternak Delima memasok susu kambing yang diproduksi untuk dijadikan susu bubuk, sabun, dan sebagainya.

3. Himpunan Peternak Domba Kambing Bogor Raya

Tempat Kelompok Ternak Delima memperoleh informasi seputar pengalaman, teknologi budidaya, pemasaran, hingga transaksi bibit unggul dengan peternak lain yang tergabung di dalamnya.

4. Industri Pengolahan Tahu/Tempe

Tempat Kelompok Ternak Delima membeli ampas tahu untuk kebutuhan pakan ternak.

\section{Aspek Finansial}

\section{Arus Manfaat (Inflow)}

Inflow merupakan pendapatan dari suatu usaha. Inflow usaha ternak kambing perah PE di Kelompok Ternak Delima terdiri atas penerimaan utama dan penerimaan sampingan.

1. Penerimaan Utama

Penerimaan utama berasal dari penjualan susu kambing. Produksi susu kambing di Kelompok Ternak Delima mencapai rata-rata 0,6 liter per ekor per hari. Harga jual susu kambing mencapai Rp30.000 per liter. Rincian penerimaan penjualan susu kambing dapat dilihat pada Tabel 3.
Tabel 3 Penerimaan Penjualan Susu Kambing di Kelompok Ternak Delima per Tahun, 2019

\begin{tabular}{cccr}
\hline Tahun & $\begin{array}{c}\text { Jumlah } \\
\text { Laktasi } \\
\text { (ekor) }\end{array}$ & $\begin{array}{c}\text { Produksi } \\
\text { (liter) }\end{array}$ & \multicolumn{1}{c}{$\begin{array}{c}\text { Penerimaan } \\
\text { (Rp) }\end{array}$} \\
\hline 1 & 5 & 1095 & 32.850 .000 \\
2 & 7 & 1533 & 45.990 .000 \\
3 & 8 & 1752 & 52.560 .000 \\
4 & 11 & 2409 & 72.720 .000 \\
5 & 18 & 3942 & 118.260 .000 \\
\hline
\end{tabular}

Sumber : Data Primer, 2019 (diolah)

2. Penerimaan Sampingan

Penerimaan sampingan berasal dari penjualan kefir dan kambing bibit. Penjualan kefir dimulai pada tahun ke2 investasi, sedangkan penjualan kambing bibit dimulai pada tahun ke-4 investasi. Penjualan kefir rata-rata mencapai 120 liter per tahun dengan harga jual Rp80.000 per liter, sedangkan penjualan kambing bibit rata-rata mencapai 50 ekor per tahun dengan harga rata-rata sebesar $\mathrm{Rp}$ 2.500.000 per ekor.

\section{Arus Keluar (Outflow)}

Outflow merupakan aliran kas yang dikeluarkan oleh suatu usaha yang dijalankan. Outflow usaha ternak kambing perah PE di Kelompok Ternak Delima meliputi biaya investasi dan biaya operasional.

1. Biaya Investasi

Biaya investasi terdiri atas biaya lahan, biaya pembuatan kandang, biaya pengadaan kambing, dan pengadaan peralatan-peralatan lainnya yang digunakan sebagai penunjang kegiatan produksi. Total biaya investasi mencapai Rp336.195.000. Secara lebih rinci kebutuhan biaya investasi dapat dilihat pada Lampiran 1.

2. Biaya Operasional

Biaya operasional terdiri atas biaya variabel dan biaya tetap. Biaya variabel meliputi biaya pengadaan konsentrat, pembelian obat-obatan, upah tenaga kerja, hingga biaya 
transportasi/bensin. Biaya variabel total sebesar Rp13.425.000. Biaya tetap terdiri atas Pajak Bumi dan Bangunan (PBB), pajak kendaraan, biaya listrik, gaji karyawan, dan penyusutan. Total biaya tetap mencapai Rp 28.999.000. Secara lebih rinci kebutuhan biaya variabel dan biaya tetap dapat dilihat pada lampiran 2 dan lampiran 3.

\section{Laporan Laba Rugi}

Analisis laba rugi pada usaha ternak kambing PE di kelompok Ternak Delima meliputi perhitungan penerimaan, biaya tetap, biaya variabel, serta pendapatan yang dihitung selama 5 tahun atau selama umur ekonomis usaha. Rincian laba rugi usaha ternak kambing perah PE di Kelompok Ternak Delima dapat dilihat pada table 4 berikut:

Tabel 4 Laporan Laba Rugi Usaha Ternak Kambing Perah PE di Kelompok Ternak Delima selama 5 Tahun

\begin{tabular}{llr}
\hline No & Rincian & Jumlah (Rp) \\
\hline 1 & Penerimaan & 873.540 .000 \\
2 & Biaya Tetap & 99.975 .000 \\
3 & Biaya Variabel & 56.205 .000 \\
\hline 4 & Laba-Bersih/ & 717.360 .000 \\
& Pedapatan & \\
\hline 5 & B/C Ratio & 4,59 \\
\hline
\end{tabular}

Sumber : Data Primer, 2019 (diolah)

Rata-rata pendapatan yang dihasilkan dalam usaha ini yaitu sebesar Rp121.466.000 per tahun.

\section{Analisis Kelayakan Finansial}

Sebelum dilakukan perhitungan kriteria investasi, maka terlebih dahulu dibuat aliran kas (cashflow) yang dapat dilihat pada lampiran 4. Perhitungan kelayakan finansial dilakukan menggunakan tingkat suku bunga sebesar $7 \%$ berdasarkan tingkat suku bunga mikro bank BRI. Perhitungan dilakukan selama umur ekonomis proyek 5 tahun berdasarkan umur ekonomis mesin-mesin produksi. Hasil kriteria penilaian investasi dapat dilihat pada tabel 5.

Tabel 5. Kriteria Kelayakan Investasi Usaha Ternak Kambing PE di Kelompok Ternak Delima, Tahun 2019

\begin{tabular}{llc}
\hline No & Rincian & Kriteria Investasi \\
\hline 1 & NPV & Rp 237.425.562 \\
2 & IRR & $27,25 \%$ \\
3 & PI & 1,8 \\
4 & PP & 4 Tahun 4 Bulan \\
\hline
\end{tabular}

Sumber : Data Primer, 2019 (diolah)

Hasil dari perhitungan analisis finansial menunjukkan nilai NPV yaitu sebesar Rp 237.425.562. Hal ini menunjukkan bahwa usaha ini layak dijalankan selama 5 tahun karena menunjukkan NPV yang positif.

IRR yang dihasilkan yaitu sebesar $27,25 \%$. Hal ini berarti dari segi IRR layak dijalankan sebab nilai yang dihasilkan lebih besar daripada bunga pinjaman yaitu $7 \%$.

Nilai PI yang dihasilkan yaitu sebesar 1,8. Hal ini menunjukkan bahwa usaha tersebut layak untuk dijalankan. Nilai PI sebesar 1,8 berarti bahwa dengan mengeluarkan biaya sebesar Rp 1, maka peternak akan memperoleh keuntungan sebesar Rp 0,8.

PP yang dihasilkan dari perhitungan analisis finansial adalah 4 tahun 4 bulan. Hal ini menunjukkan usaha tersebut layak dengan umur ekonomis selama 5 tahun dan pengembalian investasi selama 4 tahun 4 bulan.

\section{Analisis Sensitivitas}

Analisis sensitivitas usaha ternak kambing perah PE di Kelompok Ternak Delima dapat dilihat pada Tabel 6.

Berdasarkan Tabel 6 dapat dilihat bahwa penurunan harga jual kambing merupakan parameter paling sensitif pada usaha ternak kambing perah PE di Kelompok Ternak Delima. 
Tabel 6. Analisis Sensitivitas Usaha Ternak Kambing Perah PE di Kelompok Ternak Delima, Tahun 2019

\begin{tabular}{llc}
\hline No & Uraian & $\begin{array}{c}\text { Persentase } \\
(\%)\end{array}$ \\
\hline 1 & $\begin{array}{l}\text { Maksimum Penurunan } \\
\text { Jumlah Produksi Susu }\end{array}$ & 93,83 \\
& $\begin{array}{l}\text { Kambing } \\
2\end{array}$ & $\begin{array}{l}\text { Maksimum Penurunan } \\
\text { Harga Jual Susu }\end{array}$ \\
& $\begin{array}{l}\text { Kambing } \\
3\end{array}$ & Maksimum Penurunan \\
& Harga Jual Kambing & \\
\hline
\end{tabular}

Sumber : Data Primer, 2019 (diolah)

\section{Aspek Non-Finansial}

Aspek non-finansial dianalisis menggunakan skala Likert. Adapun tingkat evaluasi aspek penilaian yang digunakan yaitu :

$1=$ sangat tidak layak

$2=$ kurang layak

3 = cukup layak

4 = layak

$5=$ sangat layak

Data yang didapat kemudian diolah menggunakan keputusan penilaian kelayakan berdasarkan besar persentase antara jawaban 1,2 dan 3,4,5 dengan keterangan 1,2 adalah tidak layak 3,4,5 adalah layak. Hasil jawaban responden kelayakan dari aspek non-finansial, indicator dan parameternya sebagaimana Tabel 7.

Tabel 7. Analisis Aspek Kelayakan NonFinansial Usaha Ternak Kambing Perah PE di Kelompok Ternak Delima, 2019

\begin{tabular}{llc}
\hline Aspek Penilaian & \multicolumn{2}{c}{ Evaluasi } \\
\cline { 2 - 3 } & 1,2 & $3,4,5$ \\
$(\%)$ & $(\%)$ \\
\hline Hukum & 0 & 100 \\
Pasar & 7,4 & 92,6 \\
Teknis/Operasional & 3,3 & 96,7 \\
Manajemen & 6,7 & 93,3 \\
Sosial & 9,5 & 90,5 \\
Dampak Lingkungan & 0 & 100 \\
\hline \multicolumn{2}{l}{ Sumber : Data Primer, 2019 (diolah) }
\end{tabular}

Aspek hukum dinyatakan layak. Pembahasan pada aspek hukum meliputi persyaratan badan hukum poknak serta perizinan dari otoritas setempat. Persyaratan badan hukum Kelompok Ternak Delima telah memenuhi syarat pendirian poknak dengan dilengkapi AD/ART dan rapat anggota secara berkala. Adapun perizinan usaha telah ditetapkan berdasarkan Surat Keputusan Kepala Desa Cibalung Nomor 36/KPTS/KT-KD/IX/2009.

Aspek pasar dinyatakan layak. Pembahasan aspek pasar meliputi permintaan dan penawaran susu kambing, permintaan dan penawaran kambing, persaingan dengan peternak lain, serta harga jual susu kambing maupun kambing yang ada di Kelompok Ternak Delima. Permintaan susu kambing cukup banyak terutama dari tempat pengolahan, namun penawaran yang ada belum tersedia. Permintaan akan kambing dari konsumen cukup banyak dan penawaran dari poknak sering tersedia. Persaingan dengan peternak lain sama sekali tidak menimbulkan dampak negatif terhadap anggota Kelompok Ternak Delima. Harga jual susu kambing dan kambing dirasa sangat menguntungkan dan jarang merugikan pihak Kelompok Ternak Delima.

Aspek teknis atau operasional dinyatakan layak. Pembahasan pada aspek teknis meliputi ketersediaan bahan baku untuk pakan, ketersediaan obat-obatan, ketersediaan lahan dan kandang, serta kegiatan produksi yang dilakukan.

Ketersediaan bahan baku untuk pakan maupun obat-obatan mudah dijumpai di sekitar area poknak. Ketersediaan lahan dan kandang didukung oleh keadaan tanah yang padat sehingga kandang tidak mudah rubuh. Kandang yang digunakan merupakan kandang dengan sistem panggung yang terbuat dari kayu/bambu beratapkan genteng maupun asbes. Kegiatan produksi yang dilakukan sama sekali tidak menimbulkan masalah berarti. Kambing diberikan pakan kehijauan 
dengan sedikit konsentrat pada pagi, siang, dan sore. Pemerahan dilakukan setiap pagi dan sore hari. Selain itu, kotoran kambing selalu dibersihkan secara berkala apabila kotoran sudah sudah memenuhi parit penampung yang berada di bawah kandang.

Aspek manajemen dinyatakan layak. Pembahasan aspek manajemen meliputi sistem manajemen, peningkatan kualitas SDM, dan tingkat pendapatan anggota. Sistem manajemen dijalankan sesuai dengan kesepakatan anggota yang mengacu pada AD/ART yang dibentuk. Peningkatan kualitas SDM biasa dilakukan dengan pelatihan yang diikuti anggota secara bergilir. Serta tingkat pendapatan anggota berasal dari penjualan susu, penggemukan, dan pembibitan kambing dirasa cukup untuk menfkahi keluarga.

Aspek sosial dinyatakan layak. Pembahasan aspek sosial meliputi manfaat usaha serta hubungan dengan masyarakat. Kelompok Ternak Delima mampu berkonstribusi demi masyarakat dalam hal penyediaan bibit kambing, penyebaran informasi seputar budidaya kambing, menyediakan lapangan kerja, hingga menyediakan pupuk untuk petani sekitar. Keberadaan Kelompok Ternak Delima telah menjadi wadah kebersamaan bagi warga sekitar untuk membangun perekonomian bersama yang telah dibuktikan dengan semangat gotongroyong dalam hal pembuatan kandang.

Aspek dampak lingkungan dinyatakan layak. Pembahasan aspek dampak lingkungan meliputi dampak terhadap udara, air, juga terhadap kesehatan masyarakat. Tidak ada dampak negatif yang ditimbulkan baik terhadap udara, air, maupun kesehatan masyarakat sekitar. Selain itu untuk mencegah bau tidak sedap, anggota maupun peternak tidak akan membiarkan urin kambing tergenang begitu saja sehingga memicu bau tidak sedap.

\section{KESIMPULAN DAN IMPLIKASI KEBIJAKAN}

\section{Kesimpulan}

Dari hasil penelitian usaha ternak kambing perah PE di Kelompok Ternak Delima dapat disimpulkan bahwa :

1. Keragaan usaha ternak kambing perah PE di Kelompok Ternak Delima yaitu : mayoritas anggota berada pada kisaran usia 40-49 tahun, mayoritas anggota berpendidikan SLTP/sederajat, mayoritas anggota memiliki pengalaman rata-rata lebih dari 20 tahun dalam beternak kambing, mayoritas anggota berprofesi pada bidang lain selain beternak, sumber modal terbesar berasal dari modal sendiri, pemasaran yang dilakukan yaitu dari Poknak ke tempat pengolahan sebagai prioritas utama.

2. Usaha ternak kambing perah PE di Kelompok Ternak Delima adalah layak dengan hasil kriteria penilaian meliputi NPV sebesar Rp139.329.038 yang dinyatakan layak karena lebih dari 0, IRR sebesar 119,99\% yang dinyatakan layak karena lebih besar dari bunga pinjaman sebesar 7\%, PI sebesar 1,5 yang mana dengan mengeluarkan biaya $\mathrm{Rp} 1$ maka akan diperoleh keuntungan sebesar Rp 0,5, dan PP selama 4 tahun 4 bulan dinyatakan layak sebab lebih kecil dari umur ekonomis usaha yaitu selama 5 tahun, dan

3. Analisis sensitivitas usaha ternak kambing perah PE di Kelompok Ternak Delima menunjukkan bahwa maksimum penurunan jumlah produksi susu sebesar 54,02\%, maksimum penurunan harga jual susu kambing sebesar 53,33\%, dan maksimum penurunan harga jual kambing sebesar 47,23\%. Hal ini menunjukkan bahwa penurunan harga jual kambing merupakan parameter paling sensitif 


\section{Implikasi Kebijakan}

Beberapa saran yang dapat penulis sampaikan dalam usaha ternak kambing perah PE di Kelompok Ternak Delima :

1. Kelompok Ternak Delima sebaiknya membuat arus pemasukan dan arus pengeluaran dari transaksi yang dilakukan secara lebih terperinci dalam periode per tahun mengenai usaha ternak yang dijalankan.

2. Kelompok Ternak Delima sebaiknya menjadikan kegiatan usaha ternak kambing perah PE secara lebih intensif agar dapat meningkatkan produksi susu kambing, dan

3. Bagi pemerintah agar mempertimbangkan susu kambing sebagai sumber nutrisi yang baik untuk perkembangan anak-anak Indonesia yang dapat dikonsumsi sesuai selera anak-anak, maka dari itu penting mendukung pengembangan inovasi produk susu kambing untuk dijadikan makanan olahan yang dilirik konsumen anak-anak.

\section{DAFTAR PUSTAKA}

Agustina T. 2016. Outlook Komoditas Pertanian Subsektor Peternakan: Susu. Jakarta: Pusat Data dan Informasi Pertanian Sekretariat Jenderal Kementerian Pertanian.

BPS. 2018. Populasi Kambing Menurut Provinsi, 2014-2018. Jakarta: Badan Pusat Statistik. [6 Agt 2019].

Fahmi I. 2014. Studi Kelayakan Bisnis dan Keputusan Investasi. Edisi Pertama. Jakarta: Mitra Wacana Media

Gittinger J P. 2008. Analisa Ekonomi Proyek-proyek Pertanian. Edisi Kedua. Jakarta: UI Press.

Kasmir dan Jakfar. 2017. Studi Kelayakan Bisnis. Edisi Revisi. Jakarta: Prenada Media Group.

Nazir M. 2014. Metode Penelitian. Cetakan 9. Bogor: Ghalia Indonesia.

Salim I dan Yuliana Susanti. 2016. Pemerintah Dorong Pengembangan Ternak Kambing Perah. http://ditjenpkh.pertanian.go.id/pemer intah-dorong- pengembanganternak-kambing- perah. [5 Des 2019]. Sodiq A dan Zainal Abidin. 2008. Meningkatkan Produksi Susu Kambing Peranakan Etawa. Cetakan Kedua. Jakarta: Agromedia Pustaka. 
Lampiran 1 Kebutuhan Biaya Investasi di Kelompok Ternak Delima, 2019

\begin{tabular}{|c|c|c|c|c|c|c|c|c|}
\hline No & Jenis Investasi & Volume & Satuan & Harga/Satuan (Rp) & Jumlah (Rp) & $\begin{array}{l}\text { Umur Ekonomis } \\
\text { (Tahun) }\end{array}$ & Nilai Sisa (Rp) & Penyusutan (Rp) \\
\hline 2 & Kandang 1 & 2 & unit & 20.000 .000 & 40.000 .000 & 15 & 7.500 .000 & 833.333 \\
\hline 4 & $\begin{array}{l}\text { Kambing Dara } \\
\text { Kambing Jantan }\end{array}$ & 40 & ekor & 1.100 .000 & 44.000 .000 & 5 & 700.000 & 80.000 \\
\hline 5 & Muda & 10 & ekor & 1.500 .000 & 15.000 .000 & 5 & 1.100 .000 & 80.000 \\
\hline 6 & Kulkas & 2 & unit & 2.875 .000 & 5.750 .000 & 5 & 1.150 .000 & 345.000 \\
\hline 8 & Pertemuan & 1 & unit & 8.500 .000 & 8.500 .000 & 15 & 1.700 .000 & 453.333 \\
\hline 9 & Sepeda Motor & 2 & unit & 6.250 .000 & 12.500 .000 & 5 & 3.500 .000 & 550.000 \\
\hline 10 & Mesin Rumput & 1 & unit & 4.700 .000 & 4.700 .000 & 5 & 950.000 & 750.000 \\
\hline 11 & Milk Can & 1 & unit & 170.000 & 170.000 & 5 & 100.000 & 14.000 \\
\hline 12 & Sealer & 1 & unit & 275.000 & 275.000 & 5 & 180.000 & 19.000 \\
\hline 13 & Gentong & 4 & unit & 175.000 & 700.000 & 5 & 100.000 & 15.000 \\
\hline 18 & Parang & 3 & unit & 50.000 & 150.000 & 5 & 25.000 & 5.000 \\
\hline 19 & Arit & 2 & unit & 75.000 & 150.000 & 5 & 50.000 & 5.000 \\
\hline 20 & Ember & 20 & unit & 8.000 & 160.000 & 1 & 0 & 8.000 \\
\hline 21 & Garpu & 2 & unit & 80.000 & 160.000 & 5 & 50.000 & 6.000 \\
\hline \multirow[t]{2}{*}{22} & Listrik & 1 & unit & 750.000 & 750.000 & 10 & 375.000 & 37.500 \\
\hline & Total & & & & 336.155 .000 & & 108.210 .000 & 4.735 .000 \\
\hline
\end{tabular}

Sumber : Data Primer, 2019 (diolah) 
Lampiran 2 Kebutuhan Biaya Variabel di Kelompok Ternak Delima per Tahun, 2019

\begin{tabular}{lclrr}
\hline Uraian & Kuantitas & Satuan & Harga/Satuan (Rp) & Jumlah (Rp) \\
\hline Konsentrat & & & & \\
\hline Konsentrat BET 50 kg & 18 & Karung & 250.000 & 4.500 .000 \\
Ampas Tahu 20 kg & 18 & Karung & 20.000 & 360.000 \\
Dedak 20 kg & 18 & Karung & 80.000 & 1.440 .000 \\
Kapur Pertanian 5 kg & 12 & Karung & 50.000 & 600.000 \\
\hline Total Biaya Konsentrat & & & & 6.900 .000 \\
\hline Obat-obatan & & & & \\
\hline Kalbazen-SG 1L & 1 & Pak & 510.000 & 210.000 \\
Colibact Bolus 12 & 1 & Pak & 470.000 & 55.000 \\
Ivomec 500 gr & 1 & Pak & 60.000 & 670.000 \\
Povidone Iodine 1L & 1 & Pak & 90.000 & 90.000 \\
Alkohol 70\% 1L & 1 & Pak & 120.000 & 120.000 \\
Biosan TP 100 mL & 1 & Pak & & 1.005 .000 \\
\hline Total Biaya Obat-obatan & & & 160.000 & 1.920 .000 \\
\hline Upah & 12 & Bulan & 300.000 & 3.600 .000 \\
\hline Bensin & 12 & Bulan & & 13.425 .000 \\
\hline Total Biaya Variabel & & & &
\end{tabular}

Sumber : Data Primer, 2019 (diolah)

Lampiran 3 Kebutuhan Biaya Tetap di Kelompok Ternak Delima per Tahun, 2019

\begin{tabular}{lr}
\hline Uraian & Jumlah (Rp) \\
\hline Pajak Bumi dan Bangunan (PBB) & 600.000 \\
Pajak Kendaraan & 500.000 \\
Biaya Listrik & 1.200 .000 \\
Gaji Karyawan & 21.600 .000 \\
Penyusutan & 4.735 .000 \\
\hline Total Biaya Tetap & 28.635 .000 \\
\hline
\end{tabular}

Sumber : Data Primer, 2019 (diolah) 
Lampiran 4 Aliran Kas Usaha Ternak Kambing Perah PE di Kelompok Ternak Delima, Tahun 2019

\begin{tabular}{|c|c|c|c|c|c|c|}
\hline \multirow{2}{*}{\multicolumn{2}{|c|}{ Uraian }} & \multicolumn{5}{|c|}{ Tahun } \\
\hline & & 1 & 2 & 3 & 4 & 5 \\
\hline \multirow[t]{5}{*}{ A } & Inflow & & & & & \\
\hline & Susu Kambing & 32.850 .000 & 45.990 .000 & 52.560 .000 & 72.270 .000 & 118.260 .000 \\
\hline & Kefir & & 9.600 .000 & 9.600 .000 & 9.600 .000 & 9.600 .000 \\
\hline & Nilai Residu & & & & & 263.210 .000 \\
\hline & Total Inflow & 32.850 .000 & 55.590 .000 & 62.160 .000 & 206.870 .000 & 516.070 .000 \\
\hline \multirow[t]{14}{*}{1} & Biaya Investasi & & & & & \\
\hline & Lahan & 75.000 .000 & & & & \\
\hline & Kandang 1 & 40.000 .000 & & & & \\
\hline & Kandang 2 & 125.000 .000 & & & & \\
\hline & Kambing Dara & 44.000 .000 & & & & \\
\hline & Kambing Jantan & 15.000 .000 & & & & \\
\hline & Mesin Rumput & 4.700 .000 & & & & \\
\hline & Milk Can & 170.000 & & & & \\
\hline & Sealer & 275.000 & & & & \\
\hline & Gentong & 700.000 & & & & \\
\hline & Gelas Ukur & 75.000 & & & & \\
\hline & Pompa Air & 275.000 & & & & \\
\hline & Cangkul & 180.000 & & & & \\
\hline & Golok & 160.000 & & & & \\
\hline & iran 4 Lanjutan & & & & & \\
\hline
\end{tabular}




\begin{tabular}{|c|c|c|c|c|c|c|}
\hline & Parang & 150.000 & & & & \\
\hline & Arit & 150.000 & & & & \\
\hline & Garpu & 160.000 & & \multicolumn{3}{|c|}{160.000} \\
\hline & Total Biaya Investasi & 336.155 .000 & & & 160.000 & \\
\hline \multirow[t]{4}{*}{2} & Biaya Tetap & & & & & \\
\hline & PBB & 600.000 & 600.000 & 600.000 & 600.000 & 600.000 \\
\hline & Gaji Pegawai & & & 21.600 .000 & 21.600 .000 & 21.600 .000 \\
\hline & Total Biaya Tetap & 2.300 .000 & 2.300 .000 & 23.900 .000 & 23.900 .000 & 23.900 .000 \\
\hline \multirow[t]{7}{*}{3} & Biaya Variabel & & & & & \\
\hline & Konsentrat BET & & & 4.500 .000 & 4.500 .000 & 4.500 .000 \\
\hline & Ampas Tahu & 360.000 & 360.000 & 360.000 & 360.000 & 360.000 \\
\hline & Bensin & 3.600 .000 & 3.600 .000 & 3.600 .000 & 3.600 .000 & 3.600 .000 \\
\hline & Total Biaya Variabel & 7.005 .000 & 8.925 .000 & 13.425 .000 & 13.425 .000 & 13.425 .000 \\
\hline & Total Outflow & 345.460 .000 & 11.225 .000 & 37.325 .000 & 37.485 .000 & 37.325 .000 \\
\hline & Net Benefit & -312.610 .000 & 44.365 .000 & 24.835 .000 & 169.385 .000 & 478.745 .000 \\
\hline $\mathrm{C}$ & Discount Factor (7\%) & 0,9346 & 0.8734 & 0.8163 & 0.7629 & 0.7130 \\
\hline $\mathrm{D}$ & PV/tahun & -292.158 .879 & 38.750 .109 & 20.272 .758 & 129.223 .005 & 341.338 .568 \\
\hline $\mathrm{E}$ & PV Positif & 529.584 .879 & & & & \\
\hline $\mathrm{F}$ & PV Negatif & -292.158 .879 & & & & \\
\hline $\mathrm{G}$ & NPV & 237.425 .562 & & & & \\
\hline $\mathrm{H}$ & IRR & 27,25 & & & & \\
\hline
\end{tabular}




\begin{tabular}{llr}
\hline I PI & 1,8
\end{tabular}

4 Tahun 4 Bulan

Sumber : Data Primer, 2019 (diolah) 